\title{
Fumaria indica (L), a Famous Medicinal Herb of Tribal Regions of Jabalpur, Madhya Pradesh: Broad Spectrum Antibacterial and Phytochemical Profilng Against Some Pathogenic Microorganisms
}

\author{
Shoket Ali ${ }^{1} *$, Shikha Bansal ${ }^{2}$, Ravi Prakash Mishra'
}

Shoket Ali ${ }^{1, *}$, Shikha Bansal ${ }^{2}$, Ravi Prakash Mishra'

'Environmental biotechnology lab, Department of Post Graduate Studies and Research in Biological Science, Rani Durgavati University, Jabalpur, Madhya Pradesh, INDIA.

${ }^{2}$ Department of Botany and Microbiology St. Aloysius College (Autonomous) Jabalpur, Madhya Pradesh, INDIA.

\section{Correspondence}

\section{Shoket Ali}

Environmental biotechnology lab, Department of Post Graduate Studies and Research in Biological Science, Rani

Durgavati University, Jabalpur, Madhya

Pradesh, INDIA.

E-mail: shoketa00@gmail.com

History

- Submission Date: 28-01-2020

- Review completed: 22-02-2020;

- Accepted Date: 16-03-2020.

DOI : 10.5530/pj.2020.12.92

Article Available online

http://www.phcogj.com/v12/i3

Copyright

(C) 2020 Phcogj.Com. This is an openaccess article distributed under the term of the Creative Commons Attribution 4.0 International license.

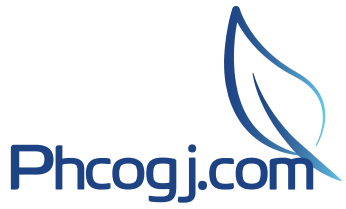

\section{ABSTRACT}

This work describes the broad spectrum antibacterial properties of methanolic and chloroform extracts of Fumaria indica herb in different concentrations $(50 \mathrm{mg} / \mathrm{ml}, 100 \mathrm{mg} / \mathrm{ml}$ and $150 \mathrm{mg} /$ ml) against Bacillus subtilis(MTCC 10110), Staphylococcus aureus(MTCC96), Escherichia coli (MTCC 77), Pseudomonas aeruginosa (MTCC1688) and Klebsiella pneumonia (MTCC4032) using agar well diffusion method compared to standard antibiotic ciprofloxacin. Results have shown significant activities against the tested microorganisms viz., Staphylococcus aureus, Escherichia coli, Pseudomonas aeruginosa than other strains. Minimum inhibitory as well as minimum bactericidal concentrations against Bacillus subtilis and Klebsiella pneumonia were evaluated. The study indicates the possible potentiality of $F$. indicato act as an active antibacterial agent in the modern drug formulations. As the target plant species serves for the tribal medicinal purpose in several tribal regions of Madhya Pradesh, hence, the aim of the present study is to link comparatively the possible traditional use of this herb with the modern antibiotic usage.

Keywords: Fumaria indica, Antibacterial activity, Zone of Inhibition, Tribes, Phytochemicals.

\section{INTRODUCTION}

Fumaria indica (L.) belongs to family Fumariaceae, and genus Fumaria commonly called shahtera "Pit papra" in the tribal vernacular. It is an annual herb and it's distributed all over Asia, Europe and Africa. It is a familiar weed found in the plains of India. F. indica have been reported various medicinal purposes to acquire pharmacological activities like antipyretic ${ }^{1}$ hepatoprotective ${ }^{2}$ hypoglycemic $^{3} \quad$ antidiarrheal $^{4} \quad$ antispasmodic $^{5}$ antihelmintic $^{6} \quad$ antieczema $^{7} \quad$ antiperiodic compound $^{8}$ liver complaints ${ }^{9}$ and scrofulous skin affections. ${ }^{10}$ Infectious diseases have threatened the continued existence of humans since very early civilizations. ${ }^{11,12}$ The folk remedies, are still as an important part of traditional medicine ${ }^{13}$ presently many human diseases and infections are cured by a diversity of plants ${ }^{14}$ or plant derivative products. ${ }^{15}$ The main cause for the continuing attention and broad research on plants for antibacterial properties is the manifestation of challenging strains of bacteria. ${ }^{16,17}$ These strains are competent to survive with the same pace as their genetic evolution requires continuous development of new drugs against them. ${ }^{18}$ Therefore, bacteria in fastidious are imposing require for new drugs. ${ }^{19}$ Infectious diseases are persistent and are major explanation of premature death all over world. ${ }^{20,21}$ The prevalence of severe infections in human beings has significantly increased all over the world and it has become the leading cause of mortality in developing countries. ${ }^{22}$
About $80 \%$ population of the world relies on plants as a natural source of medicine. ${ }^{23}$ They are used medicinally in different countries and are a source of many potent and powerful drugs. ${ }^{24}$ This study was aimed on validating the traditional use of selected medicinal plants against common bacteria, causing several human infections including Staphylococcus aureus, Escherichia coli, Pseudomonas aeruginosa, Bacillus subtilis, andKlebsiella pneumonia ${ }^{25-27}$ by evaluating their in vitro antibacterial activity. The plants investigated in this study commonly used to treat the infectious diseases and the associated symptoms are listed in (Table 1).

\section{MATERIALS AND METHODS}

\section{Plant materials and extraction}

The plant was collected from Bagrachi village of Jabalpur district. The collection was done in March, 2017. To confirm and authenticate the identified plant taxonomically, the samples were examined at State Forest Research institute (SFRI) under voucher no. 586. The plant was selected based on reports of its widespread use among the tribal communities. The collected plant materials were air-dried and finely powdered using a blender. To prepare methanol and chloroform extracts of the plant materials, $20 \mathrm{~g}$ of each powdered plant material was extracted with $200 \mathrm{ml}$ of methanol and chloroform for $48 \mathrm{~h}$ at room temperature. The extracted suspensions were filtered through Whatman No. 1 filter paper (Himedia) and the filtrates were concentrated to dryness using a rotary evaporator, to yield the crude extract (Table.2)

Cite this article: Ali S, Bansal S, Mishra RP. Fumaria indica (L), a Famous Medicinal Herb of Tribal Regions of Jabalpur, Madhya Pradesh: Broad Spectrum Antibacterial and Phytochemical Profilng Against Some Pathogenic Microorganisms. Pharmacogn J. 2020;12(3):619-23. 
Ali, et al.: Fumaria Indica (L), a Famous Medicinal Herb of Tribal Regions of Jabalpur, Madhya Pradesh: Broad Spectrum Antibacterial and Phytochemical Profilng Against Some Pathogenic Microorganisms

Table 1: Medicinal plant tested for their antibacterial activity in the study.

\begin{tabular}{|c|c|c|c|c|c|c|}
\hline Scientific name & Family & $\begin{array}{l}\text { Voucher } \\
\text { number }\end{array}$ & $\begin{array}{c}\text { Common } \\
\text { name }\end{array}$ & Local name & Parts used & Traditional use \\
\hline Fumaria indica $(\mathrm{L})$ & fumariaceae & 586 & shahtera & pitpapra & Whole plant & $\begin{array}{l}\text { digestion, chronic dysentery, } \\
\text { diarrhea, } \\
\text { Intoxication, fever, inflammations, } \\
\text { liver complaints, skin infection, } \\
\text { vomiting and antihelminthic, }\end{array}$ \\
\hline
\end{tabular}

Table 2: Yield percentage of methanol, chloroform and aqueous extract of Fumaria indica.

\begin{tabular}{ccccc}
\hline Plant & Solvent used & Weight of powderedsample $(\mathrm{g})$ & Weight of Extract $(\mathrm{g})$ & Extract yield (\%) \\
\hline Fumaria indica & Methanol & 20 & 1.57 & $7.85 \%$ \\
Fumaria indica & Chloroform & 20 & 1.98 & $2.9 \%$ \\
Fumaria indica & Aqueous & 20 & $11.6 \%$ & 2.32 \\
\hline
\end{tabular}

and then stored at $-20^{\circ} \mathrm{C}$ until further use. For the antibacterial activity assays, the extracts were dissolved in dimethyl sulfoxide (DMSO) at a concentration of 50,100 and $150 \mathrm{mg} / \mathrm{ml}$ and stored at $4{ }^{\circ} \mathrm{C}$ as stock solutions. $^{28}$

Percentage Yield $(\%)=\frac{\text { Dry weight of extract }}{\text { Dry weight of plant material }}$

\section{Procurement and maintenance of microbial culture}

Five species of bacteria viz., Escherichia coli (MTCC 77), Bacillus subtilis (MTCC 10110) Staphylococcus aureus (MTCC 96) Pseudomonas aeruginosa (MTCC 1688) and Klebsiella pneumonia (MTCC 4032) were obtained from the Microbial Type Culture Collection (MTCC) Institute of Microbial Technology, The bacterial procured cultures were sub-cultured in nutrient agar medium composition of (beef extract $3 \mathrm{~g}, \mathrm{NaCl}-5 \mathrm{~g}$, peptone $-5 \mathrm{~g}$, agar $-15 \mathrm{~g}$, distilled water $-1000 \mathrm{ml}$ ) andincubated at $37^{\circ} \mathrm{C}$. All the selected test strains were maintained and were sub-cultured after 20 days. The stock cultures of bacteria were maintained on nutrient agar slant at $4^{\circ} \mathrm{C}$ respectively.

\section{Determination of antibacterial activity}

Antibacterial activity was determined using well diffusion method. ${ }^{29}$ Petri plates were prepared with $20 \mathrm{ml}$ of sterile Muller Hinton agar media (HiMedia). Wells (6 $\mathrm{mm}$ diameter) were punched in the Muller Hinton agar and filled with plant extracts. The test cultures were swabbed on the top of the solidified media and allowed to dry for $10 \mathrm{~min}$ for compound diffusion. The tests were conducted at three different concentrations $50 \mathrm{mg} / \mathrm{ml}, 100 \mathrm{mg} / \mathrm{ml}$ and $150 \mathrm{mg} / \mathrm{ml}$ of the crude extracts. Ciprofloxacin $(25 \mu \mathrm{l})$ was used as positive control. The plates were incubated for $18-24$ hours at $37 \pm 1^{\circ} \mathrm{C}$. Zone of inhibition was recorded in millimeters using transparent (HiMedia) antibiotic zone scale and the experiment was repeated by triplicates.

\section{Phytochemical screening}

The Preliminary qualitative phytochemical screening of Funmaria indica extracts was carried out by the standard methods. ${ }^{30,31}$

\section{Test for Steriods (LibermannBurchard Test)}

$1 \mathrm{ml}$ of the crude extract was taken and dissolved in $10 \mathrm{ml}$ of chloroform and an equal volume of concentrated sulphuric acid was added by sides of the test tube. The upper layer turns red and the sulphuric acid layer showed yellow with green fluorescence. These indicate the presence of steroids. $^{32}$

\section{Test for Terpenoids (Salkowski test)}

$2 \mathrm{ml}$ of crude extract was taken and added to $2 \mathrm{ml}$ of acetic anhydride and absorption of $\mathrm{H}_{2} \mathrm{SO}_{4}$. Formations of blue, green rings indicate the presence of terpenoids. ${ }^{33^{4}}$

\section{Test for Saponins (Foam test)}

$5 \mathrm{ml}$ of crude extract was mixed with $20 \mathrm{ml}$ of distilled water and then agitated in a graduated cylinder for 15 minutes. The formation of bubbles indicates the presence of saponins. ${ }^{34}$

\section{Test for Flavonoids(Alkaline reagent test)}

$2 \mathrm{ml}$ of crude extract was treated with a few drops of $1 \mathrm{~N}$ sodium hydroxide solution and observed the formation of strong yellow color. This yellow color becomes colorless on the addition of dilute hydrochloric acid, indicating the presence of flavonoids. ${ }^{35}$

\section{Test for Phenolic Compounds (Ferric chloride test)}

Few drops of the extract were treated with $5 \%$ aqueous ferric chloride. The formation of deepblue or black color indicates the presence of phenolic compounds. ${ }^{35}$

\section{Test for Alkaloids (Mayer's Test)}

$2 \mathrm{ml}$ of crude extract was treated with 2 drops of Mayer's reagent. The presence of white creamy precipitate indicates positive test. ${ }^{35}$

\section{Test for glycosides (Fehling's test)}

An equal volume of Fehling A and Fehling B reagents were mixed together and $2 \mathrm{ml}$ of this solution was added to the crude extract and gently boiled. A brick-red precipitate appeared at the bottom of the test tube indicated the presence of reducing sugars. ${ }^{35}$

\section{Data analysis}

The experiments were performed in triplicate and data were expressed as mean \pm standard deviation (SD). The data obtained was analysed using statistical package for social sciences (SPSS- Version 20).

\section{RESULTS}

The preliminary qualitative phytochemical screening of different extract showed maximum number of phytoconstituents along with alkaloids, terpenoids, steroids, flavonoids, phenols (Table 3). The zone of inhibition of methanol and chloroform extracts of Fumaria indica on gram positive and negative bacteria at different concentrations, by using agar well diffusion method, was determined to access their antibacterial effect. Both extracts of Fumaria indica exhibited sensible antibacterial activity against five tested bacterial strains as compared to the standard antibiotic ciprofloxacin (Table 4). The highest zones of growth inhibition were exhibited by methanol and chloroform extract against all the microorganisms compared to aqueous extract are shown in figure 4.2 (a), (b) and (c). The methanol and chloroform extract produced a highest mean zone diameter of $13.00 \pm 1.00 \mathrm{~mm}, 11.00 \pm 1.00$ $\mathrm{mm}$ and $10.66 \pm 0.57 \mathrm{~mm}$ at a dose of $150 \mathrm{mg} / \mathrm{ml}$ on Staphylococcus aureus, Escherichia coli and Pseudomonas aeruginosa. Lowest zone 
Ali, et al.: Fumaria Indica (L), a Famous Medicinal Herb of Tribal Regions of Jabalpur, Madhya Pradesh: Broad Spectrum Antibacterial and Phytochemical Profilng Against Some Pathogenic Microorganisms

Table 3: Preliminary Phytochemical analysis of Funmaria indica (L).

\begin{tabular}{ccccccc}
\hline Extract & Alkaloid & Terpenoids & Steroids & Flavanoid & Phenols & Glycosides \\
\hline Aqueous & + & - & - & + & + & + \\
Methanol & + & + & + & + & + & + \\
Chloroform & + & + & + & + & + & - \\
\hline
\end{tabular}

+ Presence, -Absent,

Table 4: Inhibition Zone of methanolic and chloroform extract of $F$. indica against different bacterial strains.

\begin{tabular}{|c|c|c|c|c|c|c|c|}
\hline \multicolumn{8}{|c|}{ Zone of inhibition in $\mathrm{mm}$} \\
\hline \multirow[t]{2}{*}{ Bacterial strains } & \multicolumn{3}{|c|}{ Methanol extract } & \multicolumn{3}{|c|}{ Chloroform extract } & \multirow{2}{*}{$\begin{array}{c}\text { Ciprofloxacin } \\
25 \mu \mathrm{g} / \mathrm{ml}\end{array}$} \\
\hline & $50 \mathrm{mg} / \mathrm{ml}$ & $100 \mathrm{mg} / \mathrm{ml}$ & $150 \mathrm{mg} / \mathrm{ml}$ & $50 \mathrm{mg} / \mathrm{ml}$ & $100 \mathrm{mg} / \mathrm{ml}$ & $150 \mathrm{mg} / \mathrm{ml}$ & \\
\hline Staphylococcus aureus & $8.00 \pm 1.00$ & $12.00 \pm 1.00$ & $13.00 \pm 1.00$ & $6.00 \pm 1.00$ & $7.00 \pm 1.00$ & $10.33 \pm 0.57$ & $25.00 \pm 1.00$ \\
\hline Escherichia coli & $6.33 \pm 0.57$ & $9.33 \pm 0.57$ & $10.66 \pm 0.57$ & $1.33 \pm 1.88$ & $4.33 \pm 0.57$ & $7.00 \pm 1.00$ & $24.33 \pm 0.57$ \\
\hline Pseudomonas aeruginosa & $5.33 \pm 0.57$ & $7.00 \pm 1.00$ & $8.00 \pm 1.00$ & $7.00 \pm 1.00$ & $8.00 \pm 1.00$ & $11.00 \pm 1.00$ & $23.33 \pm 0.57$ \\
\hline Klebsiella pneumonia & $1.33 \pm 2.30$ & $5.00 \pm 1.00$ & $6.33 \pm 1.52$ & $4.66 \pm 0.57$ & $5.66 \pm 0.57$ & $8.00 \pm 1.00$ & $25.00 \pm 1.00$ \\
\hline
\end{tabular}

Values are expressed as means $\pm \mathrm{SD}$.

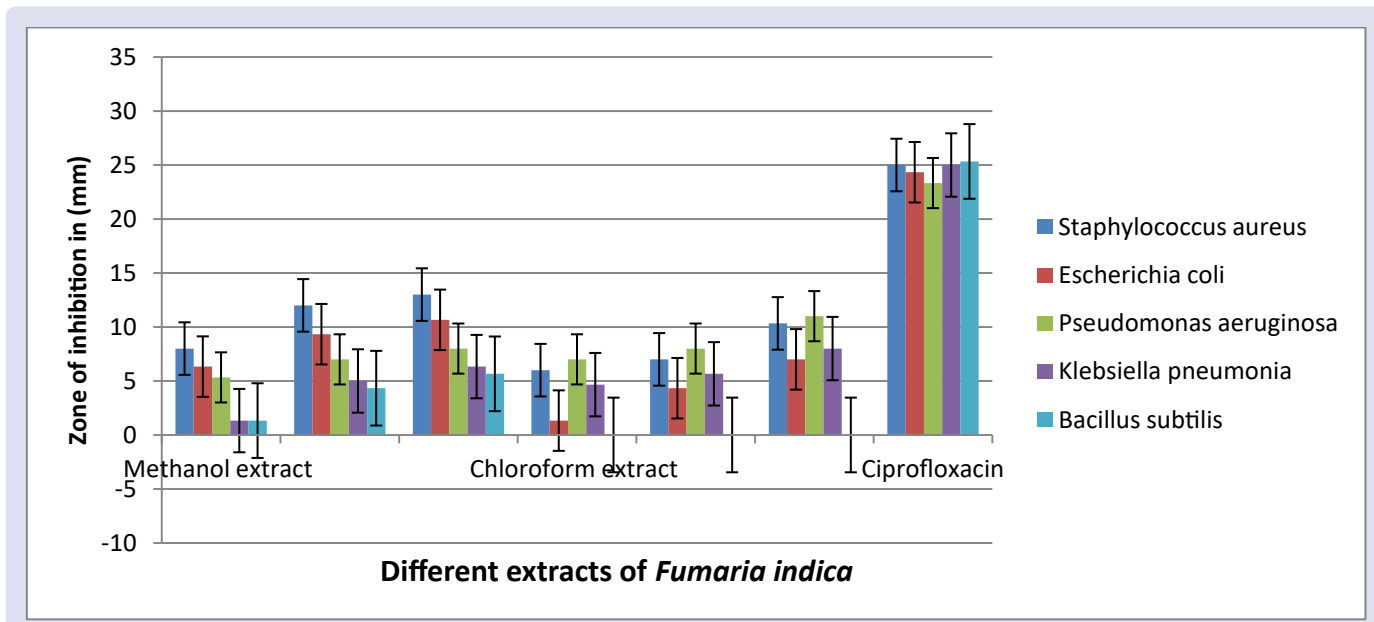

Figure 1: Inhibition Zone of methanolic and chloroform extract of $F$. indica against different bacterial strains.

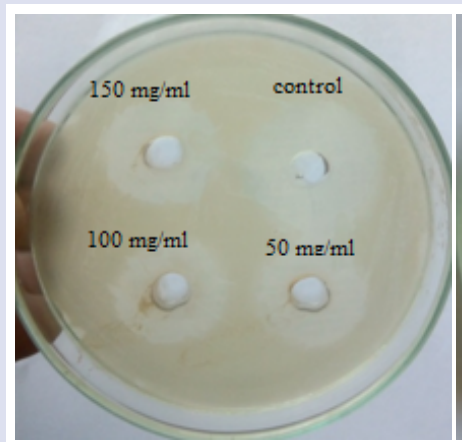

(a) Staphylococcus aureus
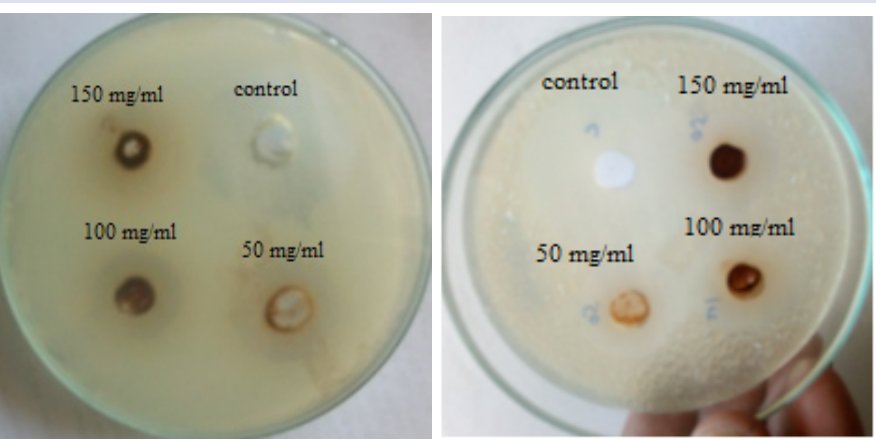

(b) Pseudomonas aeruginosa

(c) Klebsiella pneumonia

Figure 2: Antibacterial activity Fumaria indica.

of growth inhibition was observed on both extracts against Bacillus subtilis which gave a zone of inhibition measuring $1.33 \pm 2.30$ and $0.00 \pm$ 0.00 respectively at a dose of $50 \mathrm{mg} / \mathrm{ml}$ shown in (Table 4 ). The aqueous extract does not show any zone of inhibition.

\section{DISCUSSION}

Several studieshave been confirmed for the extracts of plant species possessed activity with regard to antimicrobial properties ${ }^{36,37}$ analysed that methanolic extracts of $F$. indica was very much active against Staphylococcus aureus and B. subtilis ${ }^{38}$. The study revealed that methanol and chloroform extract of the crude drug was very much effective at $E$. coli, S. aureus and P. aeruginosa and moderately effective at B. subtilis and Klebsiella pneumonia. The aqueous extract of the crude drug was moderately effective against all these test bacteria. The result of this work may add to overall value of the medicinal potential of Funmaria indica. Further chromatographic studies are required to determine 
the purified bio-active compounds responsible for the antibacterial activities which could serve as useful sources for new anti microbial agents. This experimental activity has confirmed the tribal use of the plant in the treatment of infectious diseases.

\section{CONCLUSION}

The results of the present study reveal that the antibacterial activity of traditional medicinal herb fumaria indica extracts against all the selected pathogenic bacterial strains is remarkably fascinating. This herb thus justifies its use by tribal to treat various diseases like digestion, diarrohea, fever, inflammations, liver complaints, skin infection and vomiting. This success in the beneficial role of native tribal communities hence strongly stems the fact that this plant bears the capability of possessing most important bio-conjugated constituents that could serve as a source of novel drug design formulation.

\section{ACKNOWLEDGEMENT}

Author is grateful to the University Grant Commission, New Delhi for providing (RGNF) Rajeev Gandhi National Fellowship for this study. We are thankful to the Head, Department of Post-Graduate Studies and Research in Biological Science, Rani Durgavati University, Jabalpur for providing laboratory facilities.

\section{CONFLICTS OF INTEREST}

No conflicts of interest.

\section{ABBREVIATION}

MTCC:Microbial Type Culture Collection, mg: milligram, ml: milliliter, $\mu$ l:microliter, SD: Standard deviation, $\mathrm{NaCl}$ : Sodium chloride, DMSO:Dimethyl sulfoxide.

\section{REFERENCES}

1. Kharkwal P, Ophiocordyceps sinensis and Pharmaceutical Industry. Res Rev $J$ Pharmacol Toxicol Stud. 2016;4(4):82-7.

2. Khattak SG, Gilani SN, Ikram M. Antipyretic studies on some indigenous Pakistani medicinal plants. J Ethnopharmacol. 1985;14:45-51.

3. Gilani AH, Janbaz KH, Akhtar MS, Selective protective effect of the extract from Fumaria parviflora on paracetamol-induced hepatotoxicity. Gen Pharmacol. 1996:27:979-83.

4. Akhtar MS, Khan QM, Khaliq T. Effect of Euphorbia prostrate and Fumaria indica in normoglycemic and alloxan-treated hyperglycemic rabbits. Planta Med. 1984;50:140-2

5. Rehman N, Bashir S, Al-Rehaily AJ, Gilani AH, et al. Mechanisms underlying the antidiarrheal, antispasmodic and bronchodilator activities of Fumaria parviflora and involvement of tissue and species specificity. J Ethnopharmacol. 2012;144:128-37.

6. Hordgen $\mathrm{P}$, Hertzberg $\mathrm{H}$, Heilmann J, Langhans $\mathrm{W}$, Maurer $\mathrm{V}$, et al. The anthelmintic efficacy of five plant products against gastrointestinal trichostrongylids in artificially infected lambs. Veterinary Parasitolgy 2003;117:51-60.

7. Jowkar F, Jamshidzadeh A, Yazdi AM, Pasalar M, et al. The effects of Fumaria Parviflora $L$ extract on chronic hand eczema: a randomized double-blind placebo controlled clinical trial. Iranian Red Crescent Medical Journal. 2011;13(11):824-8.

8. Khare CP. Indian herbal remedies: Rational western therapy, ayurvedic and other traditional uses botany. (2nd volume). Germany: Springer-Verlag Berlin Heidelberg; 2004;225-6.

9. Naz I, Rius JEP, Saifullah Blok V, Khan MR, Ali S, Ali B, et al. In vitro and in planta nematicidal activity of Fumaria parviflora (Fumariaceae) against the southern root-knot nematode Meloidogyne incognita. Plant Pathol. 2015;17:289-96.

10. Kirtikar KR, Basu BD, In: Indian Medicinal Plants. (Ed.): Basu Lalit Mohan. (3rd Volume). Allahabad. 1985;138. http://asi.nic.in/asi_books/2048.pdf

11. Rios JL, Recio MC. Medicinal plants and antimicrobial activity. J Ethnopharmacol. 2005; $100: 80-4$

12. Shinwari ZK, Qaiser M. Efforts on conservation and sustainable use of medicinal plants of Pakistan. Pak J Bot. 2011;43(SI):5-10.
13. Shinwari ZK, Gilani S. Sustainable harvest of medicinal plants at Bulashbar Nullah, Astore (Northern Pakistan). J Ethnophormacology. 2003;84:289-98.

14. Mahmood ARN, Malik ZK, Shinwari AM. Ethnobotanical survey of plants from Neelum, Azad Jammu \& Kashmir, Pakistan. Pak J Bot. 2011;43:105-10.

15. Walter C, Shinwari ZK, Afzal I, Malik RN. Antibacterial activity in herbal products used in Pakistan. Pak J Bot. 2011;43:155-62.

16. Gulfraz M, Sadiq A, Tariq H, Imran M, Qureshi $R$, Zeenat A, et al. Phytochemical analysis and antibacterial activity of Eruca sativa seed. Pak $J$ Bot. 2011;43(2):1351-9.

17. Shinwari ZK, Gilani SA, Khan AL. Biodiversity loss, emerging infectious diseases and impact on human and crops. Pak J Bot. 2012;44(SI):137-42.

18. Fazal H, Ahmad N, Abbasi BH, Abbass N. Selected medicinal plants used in herbal industries; their toxicity against pathogenic microorganisms. Pak J Bot 2012;44(3):1103-9

19. Zachariah SM, Muthumani P. Ramaseshu K. Phytochemsitry and antimicrobial screening of stem bark of Murraya koenigii (Linn) Spreng. The Int J Pharm. 2009;6(2):12-5

20. Parekh J, Chanda SV. In vitro antimicrobial activity and phytochemical analysis of some Indian medicinal plants. Turk J Biol. 2007;3:53-8.

21. Shinwari ZK, Khan I, Naz S, Hussain A. Assessment of antibacterial activity of three plants used in Pakistan to cure respiratory diseases. African Journal of Biotechnology. 2009;8(24):7082-6.

22. Al-Bari MA, Sayeed MA, Rahman MS, Mossadik MA. Characterization and antimicrobial activities of a phenolic acid derivative produced by Streptomyces bangladeshiensis a novel species collected in Bangladesh. Res J Med Sci. 2006;1:77-81.

23. Swarbrick J, Boylan JC. Plants as drugs. Encylopedia of Pharmaceutical Technology. New York: Marcel Dekker Inc. 2002;2(3):2214-6.

24. Srivastava J, Lambert J, Vietmeyer N. Medicinal plants: An expanding role in development. World Bank Technical Paper. 1996; 320 pp. http://documents. Worldbank.org/curated/en/ $293821468766828964 /$ Medicinal-plants.

25. Tekwu EM, Pieme AC, Beng VP. Investigations of antimicrobial activity of some Cameroonian medicinal plant extracts against bacteria and yeast with gastrointestinal relevance. J Ethnopharmacol. 2012;142:265-73.

26. Khan UA, Rahman H, Niaz Z, Qasim M, Khan J, Tayyaba, et al. Antibacteria activity of some medicinal plants against selected human pathogenic bacteria. Eur J Microbiol Immunol. 2013;3:272-4.

27. Pushparaj A, Raubbin RS, Balasankar T. Antibacterial activity of Kappaphycus alvarezii and Ulva lactuca extracts against human pathogenic bacteria. Int J Cur Microbiol App Sci. 2014;3:432-6.

28. Vu TT, Kim H, Tran VK, Dang QL, Nguyen HT, Kim H, et al. In vitro antibacterial activity of selected medicinal plants traditionally used in Vietnam against human pathogenic bacteria. BMC Complementary and Alternative Medicine. 2016;16:32.

29. Perez C, Paul M, Bazerque P. An Antibiotic assay by agar well diffusion method Acta Biologiae et Medicine Experimentaalis. 1990;15:113-5

30. Raman N, phytochemical technique. New Indian Publishing agencies. New Delhi 2006; p19.

31. Harborne JB, Phytochemical Methods. New Delhi: Springer (India) Pvt Ltd 2005; $p-17$.

32. Gibbs RD. Chemotaxonomy of Flowering Plants. Vol.1, McGill Queen's University Press. 1974;6(5):445-9.

33. Ayoola, GA, Coker HAB, Adesegun SA, Adepoju-Bello AA, Obaweya K, Ezennia EC, et al. Phytochemical screening and antioxidant activities of some selected medicinal plants used for malaria therapy in South Western Nigeria. Trop J Pharm Res. 2008;7:1019-24.

34. Kumar AR, llavarasn $T$, Jayachandran $M$, Decaraman $P$, Aravindhan $N$ Padmanaban Krishnan MRV et al. Phytochemical investigation on a tropical plant. Pak J Nutri. 2009;8:83-5.

35. Shah P, Modi HA, Shukla MD, Lahiri SK, Preliminary Phytochemical Analysis and Antibacterial Activity of Ganoderma lucidum collected from Dang District of Gujarat, India. Int J Curr Microbiol App Sci. 2014;3(3):246-55.

36. Toor Y, Nawaz K, Hussain K. Antibacterial Activity of Fumaria Indica (Hausskn.) Pugsley against Selected Bacterial Strains. Pak J Bot. 2015;47(5):2031-5.

37. Khan A, Tak H, Nazir R, Lone BA, Parry JA. In Vitro Anthelmintic and Antimicrobial Activities Of Methanolic Extracts of Fumaria indica Clin Microbial. 2014;3:5.

38. Shinwari ZK, Malik S, Karim AM, Faisal R, Qaiser M. Biological Activities of Commonly Used Medicinal Plants From Ghazi Brotha, Attock District. Pak Bot. 2015:47(1):113-20. 


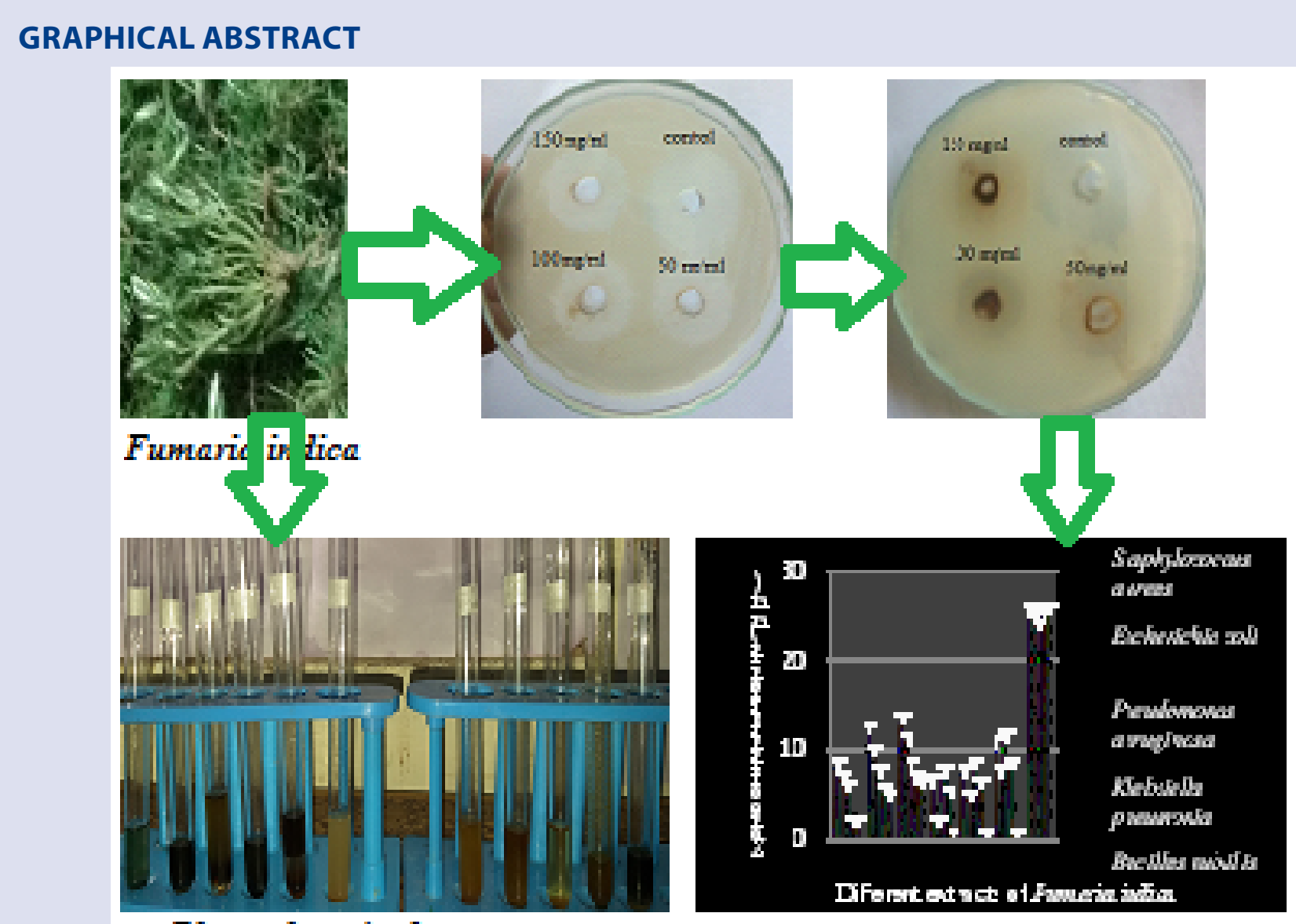

\section{Phytochemical test}

\section{ABOUT AUTHORS}

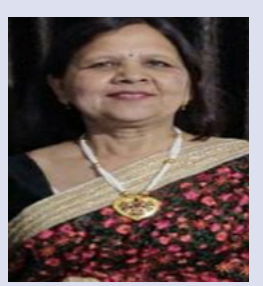

Dr. Shikha Bansal Head, Department of Botany and Microbiology St. Aloysius College (Autonomous) Jabalpur, Madhya Pradesh, India. 482001.

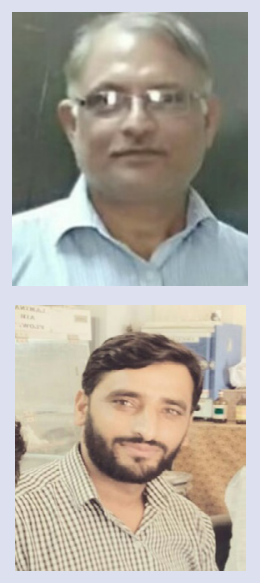

Professor, Ravi Prakash Mishra Department of Post Graduate Studies and Research in Biological Science, Rani Durgavati University, Jabalpur, Madhya Pradesh, India. 482001.

Shoket Ali Research scholar Department of Post Graduate Studies and Research in Biological Science, Rani Durgavati University, Jabalpur, Madhya Pradesh, India. 482001.

Cite this article: Ali S, Bansal S, Mishra RP. Fumaria indica (L), a Famous Medicinal Herb of Tribal Regions of Jabalpur, Madhya Pradesh: Broad Spectrum Antibacterial and Phytochemical Profilng Against Some Pathogenic Microorganisms. Pharmacogn J. 2020;12(3):619-23. 